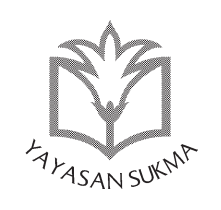

SUKMA: JURNAL PENDIDIKAN

ISSN: 2548-5105 (p), 9590 (e)

Volume 1 Issue 2, Jul-Dec 2017, hlm. 329-358

https://jurnalsukma.org/index.php/sukma/article/view/01205

\title{
JALAN TUHAN DAN KEMANUSIAAN DALAM PENDIDIKAN $^{1}$
}

\section{Abdul Munir Mulkhan}

Universitas Isam Negeri Sunan Kalijaga Yogyakarta, Indonesia email: abdul.munir@uin-suka.ac.id

\section{Abstrak}

One's faith and personality are produced during his life experience in dialogue with himself, dialogue with the nature, and dialogue with the socio-cultural environment in which he lives, grows and develops. Meanwhile, education is a planned, programmed attempt to engineer this experience of life to obtain maximum results for the future life. Education is necessarily comprehensive and synthetic. The loss of an element in education can be the cause of personality imbalances as is now the case in the reality of life in this country: motorcycle gangs, brawls between villages, corruption,

1) Bentuk awal dari paper ini pernah dipresentasikan oleh penulis pada acara Dialog Interaktif Hubungan Antar Agama Pascasarjana UKSW tanggal 5 Juli 2002 di Salatiga. 
and accusing of one another as infidel. Therefore, education process must be humanist or ngewongke and that being virtuous is the endless process of becoming. [Keimanan atau kebertuhanan dan kepribadian seseorang adalah produk pengalaman hidupnya dalam berdialog dengan dirinya sendiri, berdialog dengan alam, dan berdialog dengan lingkungan sosial-budaya tempat ia hidup, tumbuh dan berkembang. Sementara itu, pendidikan merupakan rekayasa pengalaman hidup tersebut secara terencana dan terprogram guna memperoleh hasil maksimal bagi kepentingan masa depan sejarah umat manusia. Pendidikan secara niscaya bersifat komprehensif sekaligus sintetis. Hilangnya satu unsur dalam pendidikan bisa menjadi penyebab ketimpangan kepribadian seperti yang kini banyak terjadi dalam realitas kehidupan di negeri ini: geng motor, tawuran antardesa, korupsi, dan pengkafiran satu atas yang lain. Karena itu, pendidikan mesti humanis atau ngewongke dan bahwa menjadi saleh adalah proses menjadi tanpa akhir.]

Keyword: pendidikan humanis, proses menjadi, kepribadian.

\section{Pendahuluan}

Pendidikan adalah usaha memaksimalkan peran lingkungan alam natural dan lingkungan sosial-budaya dalam mengembangkan kepribadian generasi muda, peserta didik, sehingga bisa memainkan peran signifikan dalam kehidupan di masa depan. Usaha demikian antara lain dilakukan dengan mensistematisasi pengalaman hidup sosial-budaya dalam ruang dan waktu tertentu yang dirancang secara sadar yang mampu mengembangkan suatu kepribadian sesuai rancang-bangun yang ditetapkan sebelumnya. Karena itu, kegiatan pendidikan sudah semestinya bisa memenuhi keseluruhan unsur pengembang kepribadian dalam pengalaman kehidupan sosial-budaya. 
Keseluruhan unsur kehidupan sosial-budaya tersebut seringkali dirujukkan pada Taksonomi Bloom, yaitu: kognisi, afeksi, dan psiko-motorik (Nasution 1982)

Taksonomi Bloom itu sendiri masih perlu dikritisi dalam kaitan dengan pendidikan keagamaan (Islam) yang lebih banyak melibatkan unsur spiritual religius. Sekurangnya diperlukan pengayaan pada ketiga ranah: kognisi, afeksi, psikomotorik melalui pengembangan pendekatan meta-kognisi, meta-afeksi, dan meta-psiko-motorik (Anderson and Krathwohl 2001). Pendekatan demikian akan memperkaya pemahaman para pelaku pendidikan, terutama yang berkaitan dengan dunia kehidupan peserta didik. Selain itu, pendekatan meta yang demikian itu lebih mungkin bagi pengembangan kepribadian peserta didik sesuai arahan spiritual keimanan pada kehidupan praktis.

Dalam praktik, kegiatan pendidikan lebih cenderung fokus pada salah satu ranah dari ketiga ranah kepribadian, yaitu ranah kognitif, dan kurang atau bahkan melupakan ranah afeksi dan psiko-motorik. Kecenderungan demikian lebih nampak dalam praktik pendidikan keagamaan (Islam), terutama terkait soal keimanan. Dari sinilah kita mengusulkan perlunya humanisasi atau ngewongke dalam praktik pendidikan (Islam). Suatu usaha agar pendidikan tersebut lebih menyentuh keseluruhan unsur pembentuk kepribadian peserta didik, bukan sekedar pengetahuan.

\section{Jalan Tuhan dan Jalan Kemanusiaan}

Banyak orang semakin ragu apakah hubungan antaragama dalam arti sempit atau luas, antara pemeluk beda agama dan beda paham keagamaan bisa menciptakan dunia yang lebih damai dan manusiawi pasca-September hitam 2001 lalu. Walaupun saya tetap meletakkan fundamentalisme sebagai gejala yang muncul ketika seseorang kehilangan identitas di dalam situasi krisis. Soalnya ialah bagaimana manusia yang merasa saleh itu menjadikan persoalan duniawinya sebagai persoalan dirinya dan tidak 
dengan gampang mempermainkan Tuhan bagi kepentingan ekonomi dan politik di saat tidak ada harapan dan kekuatan lain yang bisa dipakai untuk itu.

Bagi orang Amerika penghormatan pada bendera nasional, membela presiden dan bangsa adalah suatu ritual yang sama makna dan fungsinya dengan menghormat masjid bagi Muslim (Marsden 1996). Sementara orang-orang Kristiani dan Muslim atau Yahudi yang saleh juga gampang mengubah yang profan sebagai ritus yang sakral setiap saat jika itu dipandang perlu. Soalnya ialah bagaimana menafsir agamanya bagi kepentingan kemanusiaan yang sebenarnya terbuka bagi semua kemungkinan bagi radikalitas eksklusif atau akomodasi inklusif.

Konflik dan kekerasan atas nama agama atau Tuhan lebih disebabkan oleh karena pemeluk semua agama tidak konsisten dengan keyakinannya sendiri. Hubungan antarpemeluk berbeda agama atau berbeda paham keagamaan akan bisa dikembangkan lebih manusiawi, dialogis dan konstruktif jika bisa dibedakan dengan jelas yang sakral dari yang profan atau sekuler. Dalam wilayah yang disebut profan dan sekuler, pemeluk semua agama bisa bekerjasama saling menguntungkan, baik bagi kepentingan setiap agama itu sendiri atau bagi kepentingan kemanusiaan dalam arti luas.

Sayangnya pemeluk setiap agama hampir selalu berbeda dalam menempatkan dan merumuskan apa saja yang disebut sekuler dan yang sakral. Keduanya bahkan sering saling mengambil peran partisipatif, selain bisa diubah setiap saat oleh pemeluk semua agama. Batas antara yang sakral dan yang profan tidak pernah jelas dan hampir mustahil dibuat. Dengan gampang kita mengubah tindakan politik atau ekonomi sebagai tindakan atas nama Tuhan. Dan atas nama-Nya pula orang-orang yang merasa saleh terpanggil oleh suatu kewajiban menghancurkan orang lain yang berbeda agama.

Tindakan jahat dan sadis sekali pun akan berubah menjadi mulia bagai malaikat yang nanti akan diganjar surga jika dilakukan atas nama Tuhan untuk membela agama-Nya yang se- 
$\overline{\text { benarnya kita buat sendiri menurut tafsir kita sendiri. Bukankah }}$ gampang bagi kita untuk mengubah membela mereka yang teraniaya yang miskin dan tertindas yang agamanya berbeda dengan agama yang kita yakini sebagai tindakan malaikat? Soalnya ialah siapa yang mau, berani dan bersedia untuk itu tanpa dicurigai komunitas seagamanya dan dituduh telah melanggar perintah Tuhan, merusak agama-Nya dan melakukan dosa yang boleh jadi kita pun akan segera dihabisi?

Tuhan dan agama-Nya lebih sering kita pakai untuk memenuhi hasrat kerakusan kita sendiri bagaikan seorang Firaun yang ingin menjadi tuhan itu sendiri. Jika itu bisa kita capai, ketika semua orang tunduk menyerah pada kekuasaan kita dan semua orang di seluruh dunia ini mati kelaparan karena kemelaratan, kita pun kesepian seperti Firaun karena semua kekayaan dan kekuasaannya menjadi tidak berarti. Andai kita sendirilah yang nanti masuk surga, boleh jadi kita pun tidak betah karena kesepian yang senyap tanpa seorang pun teman bercakap. Inikah yang dikehendaki Tuhan dengan agama-Nya bagi manusia atau inikah yang kita cari dengan agama Tuhan?

Kita pun menjadi ragu apakah pemeluk semua agama memang dengan sungguh dan senyatanya berkehendak menjalin hubungan saling menguntungkan dan dialogis? Bukankah doktrin agama yang kita yakini mengajarkan bahwa membuat sesuatu yang mengutungkan pemeluk agama lain bisa berarti sebuah tindakan dosa. Sama halnya dengan tindakan membuat seseorang yang memeluk agama berbeda sukses dalam banyak hal dari menjadi lebih sehat, lebih makmur, atau bergembira. Kita sendiri yang telah menciptakan dunia penuh dengan setan, padahal kita bisa membuat dunia kehidupan ini dipenuhi malaikat.

Karena itu penting bagi pemeluk dan elite setiap agama untuk bisa bebas dari perangkap kategori akademik tentang yang sakral dan profan atau sekuler. Tak kalah penting ialah meletakkan apa pun tentang agama, yang sakral dan profan atau sekuler, sebagai sebuah konstruksi kemanusiaan yang bersifat kultural 
dan kebenarannya pun relatif. Melalui jalan metodik seperti itu, maka semua persoalan keagamaan bisa dinegosiasikan secara dialogis dan induktif serta demokratis. Bukankah pemeluk dari semua agama meyakini bahwa hanya Tuhan di dalam diri-Nya sendiri yang sakral dan mutlak dengan segala kesempurnaan dan kesucian-Nya?

Perdebatan tentang pemikiran dan praktik keagamaan apakah antroposentris atau teosentris, menandai dilema manusia yang ingin menjadi saleh sekaligus partisipasi atas kesakaralan, kemutlakan, dan kesucian Tuhan. Akibatnya mereka yang merasa saleh harus berlawanan dengan konsistensi dalam pemikiran, sikap dan di dalam hubungan sosial. Hubungan sosial pemeluk berbeda agama menjadi sulit dikembangkan ketika pemeluk semua agama meyakini ajaran agama yang dipeluk dan disusun dari firman atau wahyu Tuhan itu semutlak kemutlakan Tuhan.

Dalam dunia global yang membuat segala batas geografis, budaya, dan ideologis mencair, model keagamaan klasik-skolastik dengan model ketuhanan partisipatif di atas hanya akan membuat pemeluk semua agama yang ingin menjadi saleh tersingkir dari peta sosial dunia global. Di saat demikian pemeluk agama yang ingin menjadi saleh itu harus mengubah sejarah dengan segala kekuatan atas nama Tuhan yang kemungkinan besar akan kalah oleh kehebatan ilmu pengetahuan dan teknologi (iptek). Padahal iptek dan kebudayaan itu sendiri tidak lain sebagai transformasi kreatif manusia dari segala hal yang diciptakan Tuhan. Hal ini menimbulkan gejala yang disebut Karen Amstrong sebagai "fundamentalisme" agama-agama besar di dunia yang cenderung melakukan pembersihan semua orang beda agama dan beda paham keagamaan (Amstrong 2001).

Karena itu, tidak ada jalan lain bagi pemeluk agama yang ingin menjadi saleh yang sekaligus manusiawi dan pembuat sejarah duiniawi, kecuali jika kita berani melakukan tafsir ulang atas semua produk keagamaan tanpa harus takut bersalah. Bukankah Tuhan akan selalu menjadi cahaya penerang bagi hamba-Nya yang tulus berkreasi memahami ajaran-Nya dengan 
segala kemampuan yang diberikan Tuhan kepada manusia. Tuhan pun dengan sungguh bersabda agar manusia mengerahkan segala kemampuan yang disertakan bersama penciptaan manusia untuk memahami dan memenuhi ajaran-Nya.

Tuhan pun dengan sungguh bersabda bahwa Dia Maha Kuasa untuk menakdirkan manusia memeluk suatu agama, lahir di mana dan kapan akan mati. Jika kita dulu lahir di Rusia atau Cina, besar kemungkinan kita bukanlah seorang Kristen, Katolik, atau Muslim. Jika demikian, siapa yang salah ketika seseorang menjadi Kristen, Katolik, Muslim, atau Budha, Hindu, dan Konghucu? Mengapa kita tidak ikhlas menerima takdir Tuhan karena pada akhirnya Tuhan sendiri yang akan menentukan siapa yang akan masuk surga atau neraka. Mengapa pula kita merasa lebih hebat dari Tuhan lalu menjadi tuhan-tuhan kecil dan membagi jatah surga dan neraka bagi orang lain hanya karena beda agama dan beda aliran paham keagamannya?

Doktrin partisipasi ketuhanan ini menyebabkan pemeluk agama yang merasa saleh cenderung menjadi tidak manusiawi. Kesalehan bagai sebuah kepertapaan yang bebas dari segala kemanusiawian dan keduniawian karena yang kedua dianggap mengotori kesucian Tuhan dan ajaran-Nya. Praktik-praktik ritual yang bisa meluas merambah ke semua aspek keduniawian menjadi sebuah kesibukan manusia "ngurusi" Tuhan. Kita jadi heran ketika manusia menjadi salah letak dengan menganggap semua ritual merupakan sebuah pesta kesibukan memanjakan Tuhan yang menciptakan dirinya.

Patut jika kita bertanya; apakah Tuhan menurunkan rasul, nabi dan agama-Nya untuk diri Tuhan sendiri atau untuk manusia dengan segala sifat keduniawiannya? Di dalam ajaran Islam dengan tegas dinyatakan bahwa Tuhan menurunkan agama-Nya ialah untuk manusia. Seperti dengan tegas dinyatakan bahwa Tuhan hanya akan menjadi pelindung manusia jika manusia itu melindungi manusia sesamanya. Untuk manusia itu pula Tuhan mencipta semua makhluk dan dunia dengan segala isinya. Karena manusia pula Tuhan menurunkan agama-Nya dengan bahasa 
yang dikenal manusia dan bahkan dengan mengutus rasul dan nabi dari dan di antara manusia.

Di satu sisi masalah sosial, politik, dan ekonomi yang dihadapi pemeluk agama itu diyakini sebagai wilayah sekuler. Pada saat yang sama mereka meyakini bahwa ajaran agama yang dipeluknya telah lengkap mengandung semua guidance atau petunjuk bagi pemeluk untuk memecahkan semua persoalan sekuler tersebut. Dalam wilayah sekuler pemeluk semua agama yang saleh bekerjasama dan berteman laiknya saudara kandung. Namun begitu wilayah itu di-agama-kan hubungan keduanya segera berubah bagaikan hubungan setan dan malaikat.

Sementara pemeluk semua agama percaya bahwa tidak ada Tuhan lain dalam alam kehidupan dan sesudah kematian. Namun mereka menolak Tuhan yang diyakini mereka yang memeluk agama lain. Pemeluk semua agama juga percaya bahwa Tuhan Maha Kuasa, Maha Tahu dan segala Maha Takdir yang lain, tapi merasa bersalah dan berdosa jika ada orang lain memeluk agama berbeda dengan agama yang dipeluknya.

Berdasar kepercayaan dan keyakinan tunggal tentang Tuhan dan ajaran-Nya di atas seharusnya bisa dikembangkan bahwa semua Tuhan dan ajaran-Nya yang diyakini oleh pemeluk semua agama adalah Tuhan dan ajaran-Nya yang satu dan tunggal tersebut. Boleh jadi kita sendiri yang ingkar jika menyatakan bahwa konstruksi ajaran yang kita susun itu mutlak benar. Sementara kita yakin hanya Tuhan yang Maha Mutlak yang tak mungkin dikenal persis dengan obyek mutlak tersebut. Jika demikian maka kita telah meletakkan Tuhan tidak lagi Maha Mutlak dan firman-Nya tidak lagi Maha Benar karena di samping itu ada kemutlakan dan kebenaran lain yang kita buat sendiri.

Soalnya ialah tujuan kemanusiaan apa sebenarnya yang ingin kita capai dengan menjadi seorang yang saleh dan taat terhadap ajaran Tuhan. Tanpa disadari, Tuhan telah seringkali kita jadikan topeng bagi kerakusan duniawi dan surgawi kita sendiri. Melalui kecerdasannya, manusia dengan mudah memoles dan membungkus niat jahatnya dengan simbol-simbol kesakra- 
lan. Akibatnya apa yang diyakini dan dilakukan manusia dengan Tuhan dan agama-Nya tak dapat disentuh, tak dapat dikiritik dan diganggu gugat.

Karena itu penting menjadikan semua persoalan keagamaan sebagai suatu wilayah kemanusiaan yang profan dan sekuler, sehingga setiap orang terbuka dan berpeluang melakukan kritik dan mengubah sesuatu kebutuhan hidup sosialnya. Tuhan dan yang sakral bukan berubah menjadi profan dan sekuler, tapi membuatnya tetap asli di dalam wilayah ketuhanan sendiri. Sementara semua yang disentuh manusia segera berubah menjadi sekuler, kultural dan profan, karena memang demikianlah seharusnya.

Profanisasi dan pembudayaan tentang apa yang dilakukan manusia walaupun sumbernya dari Tuhan dan wahyu-Nya adalah sebuah keniscyaan. Keingkaran manusia terhadap Tuhan dan agama-Nya bukanlah hanya karena menolak kebenaran agama itu. Lebih sering keingkaran manusia karena menjadikan semua dari manusia sama mutlak dan sakralnya dengan segala yang dari Tuhan. Jika demikian, hubungan antaragama agaknya mustahil bisa melahirkan hubungan dialogis dan manusiawi bagi perdamaian seperti mustahilnya setan dan malaikat bersekutu.

\section{Pendidikan Pengayaan Penyadaran Ketuhanan}

Islam bukan sekedar agama seperti pemaknaannya di dalam pemikiran modern, melainkan keseluruhan ajaran (syariat) Tuhan tentang kehidupan manusia di dunia dan sesudah kematian. Selama masa kenabian Muahmmad Saw hingga abad-abad pertama sejarahnya, kehidupan umat Islam merupakan praktik keseluruhan ajaran syariat Allah itu yang meliputi dimensi sosial, ekonomi, politik, dan ritual hingga rekayasa teknologis sumber daya alam. Pemikir atau ulama muslim pada sejarah awal itu merupakan ahli dalam semua bidang yang dalam pemikiran modern disebut ilmu-ilmu murni dan ilmu sosial dan sains terapan (baca: filsafat, kalam, fisika, biologi, psikologi, medis, farmasi, pertanian, peternakan, dan teknologi transporta- 
si, ekonomi, sosial, politik, budaya, hingga teori perang). Idealitas dakwah dan pendidikan Islam merupakan pelembagaan pembelajaran tentang keseluruhan dimensi kehidupan tersebut.

Idealitas ke-kaffah-an Islam tersebut di atas mengalami penyempitan sesudah perpecahan politik tidak lama sesudah Islam meluas ke kawasan Eropa yang pada tahap berikut menghancurkan seluruh bangunan kekuasaan dan peradaban Islam. Keprihatinan atas kehancuran kekuasaan dan peradaban Islam melahirkan suatu gerakan pembaharuan pemikiran Islam. Gerakan ini kembali terperangkap pada godaan ideologi politik yang berhasil membebaskan negeri-negeri muslim dari penjajahan bangsa-bangsa Barat. Sentimen ideologis terhadap bangsa kolonial ini secara kurang disadari telah menyumbang penyempitan Islam menjadi sekedar agama seperti dasar pemikiran Barat modern dalam tema besar sekularisasi.

Dalam hubungan itu, kegiatan dakwah dan pendidikan Islam kemudian lebih beroperasi pada wilayah agama tersebut yang baru mulai dikaji ulang melalui proyek besar islamisasi ilmu pada akhir abad ke-20. Proyek ini seperti berjalan di tempat akibat sentimen ideologis belum benar-benar sirna yang bersama kemunduran umat dalam bidang sains modern menyababkan bidang-bidang ilmu yang semula menjadi bagian integral penelitian ulama abad-abad pertama Islam diletakkan sebagai ilmu sekuler dan ilmu ke-kafir-an. Hasil yang dicapai kemudian sekedar merupakan labelisasi Islam atas ilmu sekuler tanpa bangunan dasar epistemologi yang mapan.

Ideologisasi tersebut juga melanda pemikiran dan praktik dakwah terutama di bidang pendidikan Islam di dalam bentuk kelembagaan ilmu dan fakultas dengan akar epistemologi berbeda-beda. Tidak ada kaitan apa pun antara fakultas agama dan fakultas yang mempelajari ilmu-ilmu sekuler di dalam kelembagaan universitas Islam. Sementara fakultas agama harus menempatkan diri sebagai pengemban amanat Islam, peran signifikan dalam memandu kehidupan kongkrit umat manusia tetap berada di tangan fakultas ilmu-ilmu sekuler itu. Di sinilah 
kita patut mengajukan pertanyaan mengenai posisi pendidikan agama dengan fakultas agamanya di dalam sistem kelembagaan universitas Islam selain posisi dakwah dalam kehidupan umat manusia yang multi dimensi.

Tanpa mengabaikan problem epistemologi yang mendasari pelembagaan dan praktik dakwah atau pendidikan Islam dalam bentuk universitas atau yang sejenis di atas, mungkin kita bisa mencoba mengembangkan praktik dakwah dan pendidikan agama dalam kerangka besar pendasaran epistemologi lembaga pendidikan Islam dan dakwah tersebut. Dalam semangat itu pula uraian dan pokok pikiran makalah ini disusun dalam tema "pengembangan kepribadian atau kesadaran keagamaan" yang diharapkan bisa memberi perspektif baru wawasan ke-kaffah-an Islam dalam praktik dakwah dan pendidikan (Mulkhan 2002a).

\section{Strategi Pembelajaran}

Di tengah perkembangan pemikiran baru dalam pembelajaran yang antara lain ditandai munculnya tesis tentang kecerdasan emosional Daniel Goleman dan kecerdasan spiritual Danah Zohar, ranah pembelajaran khususnya dalam praktik pendidikan masih berada dalam model pembagian klasik: kognisi (ilmu rasional), afeksi (penyadaran/kepribadian), dan psikomotorik (keterampilan). Sementara dalam tesis baru, pembelajaran tersebut lebih mengarah pada penempatan ranah afeksi sebagai fondasi pendidikan, dalam tradisi Islam termasuk kegiatan dawah, tanpa harus mengabaikan dua ranah yang lain. Soalnya ialah sasaran apa yang paling penting dilakukan dalam pembelajaran pendidikan agama ketika pendidikan agama dipahami sebagai bagian terpisah dari pembelajaran dua ranah lainnya tersebut. Alokasi waktu yang hanya sekitar 10\% dari keseluruhan beban SKS dalam sistem pendidikan formal atau dakwah selain keterlepasannya dari keseluruhan bidang studi dan berbagai persoalan sosial dan teknologi, mengharuskan kita menentukan sasaran utama dari ketiga ranah tersebut dalam penyelenggaraan pembelajaran pendidikan agama. 
Dalam hubungan itulah makalah ini menawarkan model garden learning di luar model pembelajaran yang selama ini lebih mengutamakan ranah kognisi melalui tatap-muka di kelas. Untuk itu pendidikan agama dan dakwah, harus dipertegas bukannya sekedar pemindahan ilmu dan nilai yang dikuasai guru atau dosen dan juru dakwah kepada mereka yang disebut umat, murid, atau mahasiswa. Konsep pendidikan (dakwah) sebagai transfer nilai dan ilmu mengandaikan hanya guru dan juru dakwah yang bisa membuat takwa, sehingga murid atau seseorang akan menerima ketakwaan dari sang guru atau dai. Inilah yang dikritik keras oleh Paulo Freire sebagai model bankir dan apa yang dimaksud dalam etos guru-murid pendidikan Kiai Ahmad Dahlan.

Kerena itu beberapa pertanyaan berikut perlu dijawab jika ingin memperoleh model pembelajaran efektif dalam pendidikan agama dan dakwah. Pertama, apakah pendidikan agama dan dakwah merupakan pengayaan ilmu tentang ajaran Islam, keterampilan ritual dari segala ragam ibadah, atau pengayaan pengalaman dan penyadaran bertuhan? Kedua, lebih efektif bagi seseorang atau seorang mahasiswa menguasai secara kognitif tentang ilmu Islam selama masa kuliah atau kegiatan dakwah atau yang memiliki kesadaran kebertuhanan (iman) dan karena itu ia bergairah mencari dan membaca sendiri buku-buku tentang ilmu Islam dan dari berbagai media informasi dan melatih keterampilan ritual di luar jam-jam kuliah selama 24 jam waktu hidupnya? Ketiga, kepribadian muslim seorang mahasiswa hanya berkembang selama masa kuliah atau usia tertentu atau lebih sebagai proses sepanjang hidup? Keempat, apakah wilayah pendidikan dan dakwah hanya terbatas di dalam ruang kuliah dan majelis-majelis pengajian dan dakwah atau keseluruhan sistem dan lingkungan selama masa studi di dalam dan di luar kampus dan lembaga dakwah formal tersebut?

Tujuan dakwah dan pendidikan agama Islam dengan alokasi waktu terbatas dan terlepas dari keseluruhan pembelajaran dan dakwah yang terlalu luas, abstrak, dan simbolik, dikembangkan ke arah lebih pragmatis. Ketakwaan, kepribadian muslim dan komitmen bagi kejayaan Islam wal muslimin diletakkan sebagai 
paradigma. Ruang kelas dan ruang sosial dikembangkan sebagai media sosio-drama bagi problematisasi iptek, kehidupan sosial, ekonomi dan politik dengan menempatkan peserta didik sebagai aktor dan dosen sutradara. Soalnya bukan jumlah jam pelajaran atau tabligh dan pengajian, tetapi membuat pembelajaran dan dakwah menjadi lebih efektif sehingga ghirah dan semangat pengembangan diri peserta didik dan warga masyarakat itu tumbuh mengembang.

Dramatisasi ruang kelas dan ruang sosial tersebut bisa dimulai dari situasi aktual peserta didik dan warga masyarakat di dalam kehidupannya sehari-hari hingga masalah makro global dengan membuat ajaran Islam (aqidah, akhlak, ibadah dan muamalat) sebagai solusi. Lebih ideal jika pembelajaran bisa dilakukan di lapangan dalam suatu bentuk garden learning di dalam sebuah ruang lebih luas yang disebut learning society. Dari sini diharap bisa tumbuh suatu kemampuan yang dalam tradisi sufi disebut makrifat dan atau keterbukaan hati dan pikiran yang disebut kasyf. Dari jam pembelajaran yang sedikit itu, peserta didik akan bisa meraih banyak hal dalam rentang waktu 24 jam hidupnya.

Melalui model hadap masalah lewat ceramah singkat sejarah tokoh, peserta didik dibawa ke dalam sebuah dunia dimana mereka menjadi bagian di dalamnya. Dosen, guru dan dai perlu memahami pengetahuan dan keterampilan yang telah mereka kuasai sebelumnya (baca al-Quran, salat, puasa, dlsb) bukan mengulang yang hanya akan membosankan. Karena itu yang perlu dilakukan ialah mempertajam pengetahuan dan keterampilan awal itu sehingga berfungsi bagi berbagai masalah yang dihadapi peserta didik, keluarga dan teman-temannya. Berikutnya, pengembangan konteks pendidikan Islam dan dakwah sesuai bidang ilmu yang menjadi fokus fakultas atau jurusan serta problem sosial. Dengan demikian, materi pendidikan Islam dan dakwah bisa difungsikan sebagai kritik ilmu atau dasar etis pengembangan ilmu dari sarjana yang bersangkutan atau kritik sosial. 
Karena itu, pendidikan Islam (agama) dan dakwah bukan sekedar pengetahuan tentang Tuhan (iman), nilai, dan prinsip perilaku (akhlak), transfer pengetahuan dan nilai, keterampilan ritual dan doktrin kehidupan sosial-politik (muamalat). Wilayah pendidikan dan dakwah bukan sekadar afeksi, kognisi, dan psikomotorik, tapi meliputi dimensi spiritual-metafisik tentang peran manusia sebagai khalifah bagi kemakmuran hidup duniawi. Suatu kemampuan melihat jauh ke depan yang dalam tradisi tasauf dikenal sebagai makrifat.

Praktik pendidikan Islam dan dakwah yang lebih bersifat isolatif tidak sesuai tradisi kenabian, bahwa seorang muslim yang baik hanya bisa tumbuh dan imannya teguh jika jauh dari tradisi setan, bertentangan dengan logika dan cara Tuhan meyakinkan kehadiran diri-Nya pada umat manusia. Model ini membuat peserta didik dan warga masyarakat tidak mempunyai pengalaman langsung bagaimana menolak keburukan dan tidak memahami dan menyadari apa yang buruk dan baik, dosa dan sunnah. Pengalaman dan kisah Nabi Ibrahim mencari Tuhan dalam Al An'am menunjuk bagaimana mekanisme alam dan pengalaman empirik berfungsi mengayakan pengalaman spiritual bertuhan. $^{2}$

Para rasul yang tergolong u-lu al azmi justru muncul dari

2) Al An'am 74-79: Ingatlah ketika Ibrahim berkata pada ayahnya Azzar: "Pantaskah engkau jadikan berhala-berhala sebagai tuhan-tuhan? Sungguh aku melihat engkau dan kaummu dalam kesesatan yang nyata" (74). Demikianlah Kami perlihatkan pada Ibrahim tanda-tanda keagungan Kami di langit dan bumi, agar Ibrahim termasuk orang-orang yang yakin (75). Ketika malam jadi gelap dan melihat sebuah bintang, dia berkata: "Inilah tuhanku" tapi ketika bintang itu tenggelam, berkata: "Aku tidak suka yang tenggelam" (76). Saat melihat bulan terbit, dia berkata: "Inikah tuhanku?" Namun setelah bulan itu terbenam ia berkata: "Sungguh jika tuhan tidak memberiku petunjuk, pasti aku termasuk orang-orang yang sesat" (77). Saat melihat matahari terbit, dia berkata: "Inilah tuhanku yang lebih besar," dan ketika terbenam dia berkata: "Hai kaumku, sungguh aku berlepas diri dari apa yang kamu persekutukan." (78). Sesungguhnya aku menghadapkan diri pada Tuhan yang menciptakan langit dan bumi, cenderung pada agama yang benar, dan aku bukanlah termasuk orang-orang mempersekutukan Tuhan (79). 
pusat peradaban dan kekuasaan jahiliah atau kafir; Musa di bawah Firaun, Muhammad di dalam kekuasaan Abu Jahal dan dari lingkungan budaya amoral, Isa dalam cengkeraman kekuasaan tiran. Krisis moral dan politik yang memuncak seringkali melahirkan tokoh pengubah sejarah. Kisah-kisah di dalam Al-Quran menunjukkan pada kita bagaimana konversi ketuhanan terjadi dan komitmen ritual tumbuh. Pengabaran tentang pertumbuhan alam fauna dan flora yang merupakan bentuk-bentuk empirisasi kehadiran Tuhan merupakan berita utama dalam Al-Quran.

Seperti telah dikemukakan, ranah kognisi, afeksi, dan psikomotorik, perlu diklarifikasi, apakah penguasaan ilmu tentang Tuhan dan ajaran-Nya (kognisi), kesadaran ketuhanan (afeksi), atau keterampilan melakukan ritual (psikomotorik), atau ketiganya sekaligus yang ingin dicapai pendidikan Islam dan kegiatan dakwah yang selama ini dilakukan. Ketiga ranah, salah satu atau dua ranah itu, tidak mesti atau apa mungkin bisa dicapai melalui perkuliahan tatap muka selama dua semester atau lebih dengan masing-masing 16 kali tatap-muka selama 100 menit. Usulan yang selalu muncul untuk menambah jam kuliah hanya akan menambah beban SKS, tanpa jaminan tujuan abstrak yang ranahnya tidak jelas itu bisa dicapai.

Tujuan-tujuan afektif tentang Tuhan dan ajaran ritual seringkali lebih mudah dicapai bukan melalui kuliah ilmu-ilmu ke-islam-an, melainkan dari kaji sejarah tentang jatuh-bangunnya sebuah bangsa atau seseorang atau perkembangan alam fisik, satwa atau fauna. Studi biologi lebih mudah menumbuhkan kesadaran tentang kehadiran atau kemahakuasaan Tuhan daripada ilmu tauhid atau kalam. Sementara komitmen ritual lebih mudah tumbuh melalui pembiasaan atau latihan keterampilan ritual. Tujuan-tujuan afektif lebih efektif melalui garden learning dengan dialog atau ngobrol santai daripada ceramah tatap-muka di ruang kelas.

Selain problem bahan ajar dan metodologi, pembelajaran pendidikan Islam dan dakwah harus didasari kondisi mahasiswa dan warga yang tidak seluruhnya nol atau kosong pengetahuan, 
nol kesadaran dan nol keterampilan tentang Islam. Tesis-tesis mutakhir pembelajaran tentang kecerdasan intelektual, emosional ataukah spiritual, otak kanan atau otak kiri mahasiswa yang menjadi wilayah kerja pendidikan dan dakwah perlu dicermati. Dilihat dari pendidikan awal, banyak di antara mereka lulusan pesantren atau madrasah yang sudah menerima semua bidang pendidikan dan dakwah di TK hingga SMU/MA, anak-anak hingga dewasa, buruh hingga penguasa, selain dari khutbahkhutbah dan pengajian. Ketika dosen, guru atau dai mengajarkan tafsir atau paham yang berbeda dari yang selama ini diterima mahasiswa dan warga melalui proses pembelajaran sebelumnya, muncul konflik pribadi yang tak mudah dipecahkan.

\section{Pembelajaran Penyadaran (Afektif)}

Karena itu, pembelajaran pendidikan agama di universitas dan dakwah di masyarakat perlu dilakukan berdasar latar belakang ilmu (pendidikan awal) dan latar belakang sosial-budaya dan paradigma belajar kolektif antarmahasiswa maupun mahasiswa dengan dosennya atau seseorang dengan kelompoknya dan muballigh. Di mata Tuhan posisi dosen dan mahasiswa, umat dan ulama adalah setara yang mungkin lebih tinggi mahasiswa daripada si dosen atau umat atas ulama. Selain belajar kolektif, pembelajaran pendidikan agama dan dakwah bisa dilakukan dengan strategi belajar mandiri. Kebutuhan mahasiswa dan warga untuk membaca sendiri berbagai sumber bahan ajar atau belajar sendiri membaca Al-Quran dengan arahan dosen, merupakan tujuan awal yang perlu dicapai seorang dosen, guru, dan muballigh dalam kegiatan pembelajaran.

Terdapat hubungan ilmu dan iman, ke-intelek-an dan keiman-an, jika bukan sebab-akibat atau fungsional bahwa iman ialah buah ilmu atau ada ilmu maka ada iman. Sekurangnya, keimanan membutuhkan sejumlah ilmu tentang Tuhan dan ajaran-Nya. Dalam al-Quran kelompok masyarakat yang disebut al rāsikhūn dan ūlu al-albāb, hampir selalu disebut kelompok yang imannya paling sadar sebagai hasil kajian dan penelitian tentang 
realitas alam semesta. Soalnya ialah klarifikasi jenis ilmu dan konstruksi iman serta model hubungan keduanya.

Klarifikasi masalah-masalah di atas merupakan langkah awal dan mendasar dalam pengembangan strategi pembelajaran pendidikan agama di universitas dan dakwah di masyarakat, selain konsep apa yang dimaksud sebagai agama yang tak kalah penting seperti telah dikemukakan. Langkah ini akan memunculkan sejumlah persoalan yang perlu dicermati sebelum suatu kegiatan yang disebut pendidikan agama Islam dan dakwah dilakukan di semua jenjang pendidikan. Istilah pendidikan agama dan dakwah itu sendiri sudah merupakan masalah yang tak mudah dipecahkan, sehingga program pendidikan agama di universitas dan dakwah di masyarakat semakin rancu tanpa didasari konsep yang jelas.

Pertanyaan apakah ilmu agama Islam memang persoalan di luar ilmu hingga pendidikan agama dan dakwah dibedakan dari ilmu lain di universitas atau persoalan sosial lainnya, merupakan masalah filosofis dan teknis yang tak mudah dijawab. Sikap terbuka dan jujur tanpa pretensi teologis yang mengideologikan ilmu-ilmu Islam, diperlukan untuk bisa menjernihkan masalah ini. Beberapa ayat dalam surat Ali 'Imran dan an-Nisa' mungkin bisa dijadikan bahan renungan untuk menjawab dan mengklarifikasi banyak masalah tersebut di atas. ${ }^{3}$

3) Surat Ali 'Imran 190-191: Sesungguhnya dalam penciptaan langit dan bumi, dan silih bergantinya malam dan siang terdapat tanda-tanda bagi orang-orang yang berakal (190). (yaitu) orang-orang yang mengingat Allah sambil berdiri atau duduk atau dalam keadaan berbaring dan mereka memikirkan tentang penciptaan langit dan bumi (seraya berkata): "Ya Tuhan kami, tiadalah Engkau menciptakan ini dengan sia-sia, Maha Suci Engkau, maka peliharalah kami dari siksa neraka (191).

An Nisa' 162: Tetapi orang-orang yang mendalam ilmunya di antara mereka dan yang mukmin beriman kepada apa yang diturunkan kepadamu (Al-Quran) dan yang diturunkan sebelum-mu dan mendirikan salat, menunaikan zakat, beriman kepada Allah dan hari kemudian. Kepada orang-orang itu akan Kami berikan pahala yang besar (162).

Ali 'Imran 7: Dia menurunkan Al-Quran kepadamu di antara isinya 
Terdapat sejumlah masalah bagi pendidikan agama di universitas dan dakwah dari problem ontologis, epistemologis, aksiologis, hingga problem etis dan teologis ketika pendidikan agama dan dakwah diletakkan sebagai satu disiplin ilmu yang berdiri sendiri. Sementara seluruh teori iptek yang dipelajari di universitas merupakan hasil penelitian rasional dan sistematis dengan kebenaran relatif-probabilistik, dasar keilmuan pendidikan agama dan dakwah dianggap non-rasional dengan kebenaran mutlak. Sementara tujuan pendidikan agama dan dakwah mengubah keyakinan iman dan perilaku ibadah dan sosial melalui langkah-langkah sistematis dan metodologis, doktrin teologis menyatakan keberimanan dan kebersalehan seseorang merupakan rahmat dari Tuhan yang tak berhubungan dengan usaha kemanusiaan (pendidikan) (Mulkhan 2002b).

Evaluasi pendidikan agama dan dakwah dilihat sebagai soal jam yang dibatasi sesuai jenjang pendidikan dan dakwah tanpa penjenjangan tujuan. Pendidikan agama di universitas dan dakwah di masyarakat cenderung mengulang yang sudah diterima di SD hingga SMU atau berbagai kegiatan dakwah sebelumnya. Sementara keberimanan, kebersalehan, ketakwaan diyakini berlangsung sepanjang hidup dimana pernyataan iman sebelum seseorang meninggal dunia menjadi jaminan bagi seseorang masuk surga. Di sini klarifikasi tujuan pokok pendidikan agama dalam pendidikan formal dan dakwah di masyarakat perlu dipertegas, ketika di luar kelas tersedia beragam kegiatan dakwah, pengajian dan khutbah-khutbah dengan tujuan sama.

Selama ini, pendidikan agama di universitas dan dakwah di masyarakat diselenggarakan dengan materi pokok ilmu-

ayat-ayat muhkamat, itulah pokok isi Al-Quran dan yang lain ayat-ayat mutasyabihat. Adapun orang-orang yang dalam hatinya condong kepada kesesatan, maka mereka mengikuti ayat-ayat yang mustasyabihat daripadanya untuk menimbulkan fitnah dan untuk mencari-cari ta'wilnya, padahal tidak ada yang mengetahui ta'wil selain Allah (dan) orang-orang yang mendalam ilmunya berkata: "Kami beriman pada ayat-ayat mutasyabihat, semuanya itu dari sisi Tuhan kami." Dan tidak dapat mengambil pelajaran daripadanya melainkan orang-orang yang berakal (7). 
ilmu dalam studi Islam (Islamic Studies). Sementara pendidikan agama dan dakwah diharapkan berfungsi memperteguh iman dan ketaatan ibadah, perkuliahan tatap muka dan evaluasinya serta dakwah lebih beroperasi pada wilayah kognisi. Di satu sisi, peran dan keberadaan Tuhan menjadi isi pokok materi pendidikan agama dan dakwah, Tuhan pun tak pernah disentuh oleh hampir seluruh materi kuliah di universitas dan dakwah di masyarakat, bahkan tidak ada peran Tuhan di dalam banyak teori ilmiah sebagai bahan dasar kuliah tersebut.

\section{Fungsi Organisasi Intra dan Ekstra Kampus}

Karena itu perlu dikembangkan model belajar kolektif berbasis etos guru-murid melalui reinvention, reinquiry, reexperience. Strategi "hadap masalah" dari garden learning lebih efektif dari tatap-muka di kelas (Freire 1999; Freire 1985; Miller 1976). Strategi ini dimulai dari refleksi religiusitas dosen sendiri, ulama, atau tokoh penting dalam sejarah Islam. Melalui proses demikian bisa dipahami bagaimana seorang model atau selebriti lain yang perilaku keagamaannya berubah total hanya oleh sebab sederhana. Hal ini menunjukkan pentingnya metode penugasan atau permainan peran.

Fenomena serupa bisa dilihat dari proses kesantrian elite politik dan birokrasi atau pengusaha negeri ini sejak akhir 80 -an yang masih terus berlangsung. Gejala ini bisa menjadi bahan pengembangan strategi efektif pembelajaran pendidikan agama dan dakwah. Seperti gejala maraknya "fundamentalisme" anakanak kampus yang lebih banyak lahir dari LDK (lembaga dakwah kampus) dan RDK (ramadlan di kampus) yang tak berhubungan dengan kerja seorang dosen, guru, atau dai. Demikian pula peran UKM (unit kegiatan mahasiswa), selain organisasi ekstra; HMI, PMII, IMM dan beragam lembaga sosial, ekonomi dan politik yang lain.

Kebangkitan intelektual muda kampus yang seringkali dipandang sebagai akar tumbuhnya radikalisme merupakan fenomena sosial dan politik keagamaan mutakhir negeri ini seperti 
halnya di dalam kehidupan sosial di luar kampus. Dosen-dosen ilmu sekuler di universitas (negeri atau swasta) dan mereka yang tidak memahami ilmu agama mulai gigih menunjukkan identitas muslimnya melalui ilmu yang selama ini ditekuni dan bidang sosial yang digarap. Demikian pula aktivis LSM dari anak-anak muda muslim kampus sebagai kekuatan utama gerakan reformasi. Walaupun bentuk akhirnya belum jelas, namun gelombang santri kampus ini pada waktunya akan menjadi penting dalam sejarah Islam nasional.

Pembelajaran pada ranah kognisi tentu tetap penting, namun lebih penting jika dilakukan bersama dengan pengembangan garden learning melalui kegiatan di luar ruang kelas dalam bentuk LSM, UKM, atau ekstra kampus. Garden learning merupakan media pengayaan pengalaman ritual dan pengayaan pengalaman bertuhan. Dari sini diharapkan mahasiswa atau warga masyarakat bergairah membaca dan mencari sendiri bahan ajar dan dakwah serta melatih diri secara kolektif tentang berbagai model ritual Islam.

Masalah yang tak boleh diabaikan dosen, dan guru pendidikan agama atau juru dakwah ialah penyelesaian dialogis dan akademis pertentangan ilmu keislaman dan ilmu sekuler serta norma formal ajaran dengan realitas sosial. Konversi kesadaran dari seseorang atau sekelompok orang terhadap Tuhan dan ritual sering baru terjadi oleh sebab sederhana atau sesudah selesai kuliah. Perilaku keagamaan seringkali baru terjadi ketika diminta memainkan peran seorang muslim, padahal selama ini perilaku maksiat. Musuh muslimin terkemuka pascahijrah, kepala suku Ustamah bin Ustal, berubah menjadi pembela Islam hanya oleh perlakuan istimewa Nabi Muhammad Saw justru ketika ia menjadi tahanan dan dilepas tanpa syarat.

Pembelajaran tauhid (aqidah) difokuskan pada pengembangan kesadaran dan pengayaan pengalaman ketuhanan, tidak cukup nama dan sifat Tuhan, malaikat dan makhluk gaib. Materi sejarah bangsa dan orang-orang baik dan jahat, misteri alam, fauna, flora (lihat the discovery of the world) atau 
biologi lebih penting jika disertai kajian tentang puncak dan asal realitas secara akademik. Kajian hierarki realitas E.F. Schumacher untuk misteri alam fisik dan Imam Al Ghazali atau model emanasi (nadla-riatul faith) bagi misteri alam gaib (metafisik) bermanfaat bagi pembelajaran tauhid di universitas yang disertai bukti-bukti empirik.

\section{Pengalaman Kebertuhanan}

Sementara itu pengembangan keterampilan ritual dan kesadaran dalam bertuhan, lebih tepat jika dilakukan melalui praktik lapangan dan pengalaman, selain studi kasus dan pembelajaran model dialog bukan ceramah. Tatap-muka dengan ceramah mungkin hanya penting untuk $25 \%$ waktu yang tersedia, selebihnya studi kasus dan praktik lapangan. Kegiatan UKM dan ekstra kampus seperti LDK atau LSM bisa dikembangkan untuk pemberdayaan atau advokasi umat sebagai bagian dari pengayaan pengalaman bertuhan dan beribadah sekaligus pemecahan berbagai persoalan kehidupan umat.

Karena itu, dosen atau guru pendidikan agama dan juru dakwah wajib 'ain memahami dasar filosofis dari ilmu-ilmu alam, sosial, dan humaniora serta beragam kehidupan sosial, lebih khusus ilmu dasar yang menjadi konsentrasi fakultas atau jurusannya. Ia bertanggung jawab pada pembelajaran pendidikan agama atau sekelompok warga menjalani hidupnya. Sesuai waktu yang tersedia, lebih strategis jika kebutuhan itu dipenuhi dengan mengkaji filsafat alam, fisika, ekonomi, dan politik atau lainnya. Pendidikan lanjut bagi dosen dan guru pendidikan agama di universitas atau juru dakwah mungkin lebih tepat di bidang konsentrasi ilmu fakultas atau jurusan serta kehidupan sosial tempat mereka bertugas.

Wawasan keilmuan yang menjadi bidang kajian fakultas atau filsafat fisika dan kealaman serta sosial-humaniora, dosen atau guru agama dan juru dakwah akan mempunyai kemampuan meletakkan setiap disiplin ilmu yang dikuasai mahasiswa dan pola kehidupan sosial umat ke dalam suatu perspektif ke- 
sadaran ketuhanan. Dari sini dimensi metafisik ilmu keislaman dan kehidupan sosial bisa ditempatkan sebagai akar kesadaran kebertuhanan dari ilmu-ilmu yang selama ini disebut sekuler. Karena itu pendidikan agama bukan sekedar bagi dirinya sendiri, tetapi sekaligus sebagai bagian dari pengayaan ketuhanan dalam pembelajaran semua bidang ilmu di universitas dan dakwah kehidupan sosial tersebut.

Model pendidikan agama dan dakwah afektif selain melalui garden learning ialah mempertautkan ilmu-ilmu sekuler dan persoalan sosial ke dalam basis epistemologi metafisik ilmu keislaman. Cara ini sekaligus merupakan langkah sistematis realisasi proyek islamisasi ilmu dan islamisasi kehidupan sosial. Teori dan logika ilmu sekuler dikembangkan lebih lanjut ke dalam tataran metafisik yang menjadi dasar moral-etik seorang mahasiswa mengembangkan kepribadian di luar jam-jam kuliah tatap-muka atau sesudah terjun ke masyarakat. Pendidikan agama dan dakwah kemudian menjadi dasar bagi pengembangan hidup di luar kampus seperti yang selama ini terlihat dalam gerakan keagamaan anak-anak muda kampus.

\section{Pluralitas Kesalehan}

Sementara itu, kita juga perlu memahami bahwa fakta di lapangan menunjuk pada faham, penghayatan, praktik ke-Islaman dan kesalehan dari seseorang atau suatu masyarakat, tampak beragam dan plural. Lingkungan sosial, tempat tinggal, tingkat ekonomi dan pendidikan, serta pekerjaan merupakan faktor penting munculnya keragaman pola kehidupan keagamaan seseorang dan masyarakat. Perubahan sosial, ekonomi, dan budaya, cenderung menjadi faktor pengubah bentuk keberagamaan seseorang atau masyarakat. Hal ini menunjukkan bahwa keberagamaan atau kesalehan adalah sebagai proses sosial dan budaya yang terus berubah dan berlangsung secara bertahap di sepanjang hidup manusia.

Dakwah yang dilakukan sesuai ragam kehidupan keagamaan seseorang dan masyarakat sasaran sebagai suatu 
proses sosial-budaya itulah yang disebut dakwah kultural. Perubahan dari dakwah ini dilakukan secara bertahap sesuai kondisi sosial-budaya masing-masing orang dan masyarakat. Hal ini didasari pandangan bahwa ke-kaffah-an Islamnya seseorang atau masyarakat itu mudah, menyenangkan, dan menggembirakan yang bisa dilakukan setiap orang selama masa hidupnya. Keberagamaan sebagai proses sosial-budaya inilah yang disebut sebagai Islam kultural.

Di sisi lain, larangan dan ancaman berdasar ketentuan formal ajaran akidah, akhlak, ibadah-fikih yang bertujuan untuk mengubah pola perilaku keagamaan seseorang dan masyarakat bisa disebut sebagai dakwah struktural. Perilaku keagamaan seseorang yang belum sesuai ketentuan baku ini, disebut belum mukmin atau muslim. Dakwah struktural cenderunglebih bersifat politis, top-down, dan elitis, yang biasanya lebih mementingkan pengembangan hukum dan perundang-undangan.

Dakwah kultural memandang label atau kategorisasi sebagai; priyayi, abangan, dan santri, atau kategori; modernis, tradisonalis, sinkretik (yang di kalangan tertentu biasa dan sering disebut dengan akronim TBC (tahayul, bid'ah, dan churafat) adalah sebagai tahap-tahap keberagamaan seseorang atau masyarakat. Keberagamaan ini merupakan proses sosialbudaya yang akan berubah searah perubahan kehidupan sosial, ekonomi, dan budaya seseorang atau masyarakat. Islam disajikan di dalam beragam menu sesuai struktur sosial dan ekonomi warga masyarakatnya. Menjadi muslim itu mudah (taisir) dan menggembirakan (tabsyīr), bisa dilakukan semua orang sesuai struktur sosial-ekonomi masing-masing.

Karena itu, doktrin Islam kaffah adalah citra dan cita ideal yang bentuk kongkritnya beragam bagi setiap orang dan masyarakat. Santri; modernis atau tradisionalis, abangan atau sinkretik (pelaku TBC), seringkali merupakan fakta historis sebagai "takdir" sosial-budaya bagi seseorang ketika lahir. Jika "takdir" sosial-budayanya itu berubah, keberagamaan mereka akan berubah. Dakwah kultural bukan membuat batas di antara 
santri dan abangan, modernis dan tradisionalis, sinkretik dan Islam murni, menajam dan mengeras, tetapi mempercepat perubahan itu melalui upaya pemberdayaan atau advokasi sosial-ekonomi dan pendidikan. Cara-cara dakwah yang cenderung merendahkan keagamaan seseorang bisa mendorongnya makin menjauh dari identifikasi diri sebagai muslim.

Kategorisasi santri atau abangan seperti di atas sebenarnya bukan ciptaan asli Clifford Geertz. Tahun 1920-an, masalah ini sudah menjadi wacana publik dan dipakai untuk menyebut perilaku keagamaan seseorang atau masyarakat. Penelitian Clifford Geertz yang dilakukan tahun 1950-an merupakan penjelasan akademik keagamaan kaum abangan di dalam bingkai struktur sosial-ekonomi petani miskin di pedesaan dan buruh di perkotaan. Priyayi muncul dari tradisi birokrasi, yang lebih dekat pada keberagamaan abangan. Sementara tradisi santri muncul dari struktur kehidupan pasar kaum pedagang. Petani santri yang miskin di pedesaan cenderung tradisionalis dan sinkretik, dan yang lebih kaya cenderung modernis. Mobilitas sosial-ekonomi petani dan buruh mendorong banyak di antara mereka yang kini menjadi lebih santri.

Dalam perkembangannya, pola hidup modern warga masyarakat yang hidup di kota, cenderung membuat mereka kehilangan pengalaman spiritual yang tidak bisa dipenuhi hanya dengan tradisi keagamaan yang serba mekanis dan sistematis yang sudah ditentukan secara baku dalam aturan fikih. Petani pedesaan dan buruh di perkotaan juga menghadapi persoalan serupa. Gejala ini terlihat dari meluasnya apresiasi praktek sufi kaum profesional dan warga kota, tarekat di pedesaan, dan tetap sulitnya petani miskin dan buruh mengapresiasi praktek keagamaan model baku dan standar sebagaimana tersusun dalam aturan formal ajaran Islam seperti yang dikenal dalam ilmu fikih atau syariah.

Praktek keagamaan kaum santri yang hidup di kawasan perkotaan dan berpendidikan lebih tinggi cenderung berbeda dibanding warga yang hidup di kawasan pedesaan, seperti perbe- 
daan perilaku keagamaan dari anggota masyarakat yang bekerja sebagai pedagang, pegawai, petani dan buruh. Sama-sama sebagai pengikut Muhammadiyah atau NU, perilaku keagamaan mereka cenderung berbeda sesuai tempat tinggal, asal-usul sosial, pendidikan dan pekerjaan mereka. Penelitian tahun 1997-1999 di Jember Jawa Timur tentang perilaku keagamaan pengikut Muhammadiyah misalnya menunjukkan adanya empat bentuk praktek Islam murni, yaitu model; Al Ikhlas, Kiai Dahlan, Munu (Muhammadiyah-NU), dan Marmud (Marheinis-Muhammadiyah) atau Munas (Muhammadiyah-Nasional) dari warga Muhammadiyah yang seluruhnya secara resmi terdaftar sebagai anggota organisasi ini. Penelitian Riaz Hassan juga melaporkan kecenderungan santri tradisionalis yang seringkali dikaitkan dengan kepengikutan dalam organisasi NU yang mulai berubah searah migrasi mereka ke kawasan perkotaan dan naiknya tingkat pendidikan. Perubahan keempat bentuk praktek Islam dari pengikut Muhammadiyah atau NU akan ditentukan oleh bagaimana ajaran Islam itu didakwahkan dan di kawasan mana seseorang itu menjalani hidupnya.

Jika kita membagi praktek Islam dalam dua model, yaitu: syariah dan sufi, model pertama lebih mudah diterima kaum pedagang, pegawai, dan kelas sosial lebih tinggi, dan model kedua lebih mudah diterima petani, buruh, dan yang mengalami transisi sosial-budaya, atau juga masyarakat industri yang mengalami rasionalisasi dan materialisasi besar-besaran. Praktek Islam model pertama dikembangkan melalui dakwah sebagai rasionalisasi, dan yang kedua melalui spiritualisasi atau sufistisasi atau penyadaran ketuhanan yang lebih menekankan dimensi etik suatu ajaran.

Dakwah kultural sekurangnya menyajikan Islam dalam beragam menu yang berbeda bagi masyarakat yang berbeda. Menu aturan formal syariah atau fikih dalam tradisi Muhammadiyah yang tersusun dalam buku tarjih tentu penting bagi aktivis Muhammadiyah dan warga kota yang berpendidikan lebih tinggi. Namun dakwah yang bisa membuat orang gembira dan berpengharapan (tabsyīr) bahwa menjadi muslim itu mudah (taisir) lebih 
sesuai bagi mayoritas umat di negeri ini. Sementara menu sufi atau spiritualisasi penting bagi warga pedesaan atau pun kaum profesional dan buruh di perkotaan.

Dakwah bagi masyarakat abangan lebih mungkin dilakukan dengan menu etika syariah melalui spiritualisasi atau sufistisasi dan penyadaran afektif. Demikian pula bagi masyarakat di pedesaan, petani, buruh, dan kaum elite di perkotaan. Mungkin sudah perlu dilakukan semacam rasionalisasi praktik sufi seperti pernah dilakukan Hamka, bukan hanya pemurnian syariah dan akidah dari tahyul, bid'ah dan churafat (TBC). Sayang, Hamka belum mengembangkan model ritual praktek sufi bagi orang modern, para profesional, eksekutif, dan kelas elite lain, sekaligus bagi kelas bawah yang petani di pedesaan dan buruh di perkotaan.

Kriteria umat ijabah dan dakwah dalam perbincangan tentang sasaran dakwah, bukan berarti posisi umat dakwah lebih rendah dibanding umat ijabah, dan sebaliknya di mata Tuhan. Penurunan Al-Quran di dalam waktu 23 tahun sesuai problem aktual yang dihadapi Rasul dan umat, menunjukkan tahapan perubahan menjadi muslim tersebut. Sunnah Rasul lahir sebagai proses dialogis atas tradisi kehidupan yang hidup waktu itu yang berbeda bagi setiap orang dan masyarakat (Mulkhan 2002c).

Sumber normatif dan historis dakwah kultural bisa dikaji dari Al-Quran dan Sunnah, serta dari dakwah penganjur Islam di Tanah Air. Surat Ibharim ayat 4 (wa mā arsalnā min rasūlin illā bilisāni qaumihi liyubayyina lahum fayuḍillu allāhu man yasyā'u wa yahdī man yasyā'u wa huwa al-'azīzu al-hakìm) menyatakan Nabi Muhammad Saw dan para rasul diutus berdakwah sesuai kondisi sosial, politik, ekonomi dan budaya masyarakat. Banyak kisah dalam sejarah kenabian Muhammad Saw yang bisa dijadikan rujukan dakwah kultural.

Pemahaman seperti di atas juga bisa dipahami dari suatu kisah berlatar historis usai Perang Chandak tahun ke-6 pasca hijrah. Waktu itu Tsumamah bin Utsal, kepala suku Hanifah, seorang dari raja-raja Yamamah, musuh besar Islam ditawan 
tentara dari kaum muslimin. Setiap pagi selama beberapa hari, Nabi menjamu dengan susu ontanya sendiri sebagai penghormatan kedudukan sosial Tsumamah. Walaupun tetap congkak dan menunjukkan permusuhan, ia dibebaskan tanpa syarat. Tsumamah tidak bergegas kembali ke kaumnya, tetapi bersuci dan menyatakan masuk Islam. Orang yang di kemudian hari menjadi tokoh penting Islam ini masuk Islam bukan oleh ancaman neraka dan hukuman, tapi oleh perlakuan istimewa Nabi. Para sahabat, dan tokoh penting generasi awal di negeri ini, banyak berubah dari memusuhi Islam menjadi pembela Islam militan melalui jalan beragam.

Kelahiran tokoh-tokoh besar gerakan Islam; ulama, kiai, muballigh, dan atau aktivis, juga melalui beragam cara dari rasionalisasi atau spiritualisasi, bahkan humanisasi atau ngewongke (memanusiakan manusia). Fenomena demikian antara lain bisa dibaca dari kisah hidup yang dialami Tsumamah bin Utsal yang memperoleh hidayah justru oleh pelakuan humanis Rasulullah Muhammad Saw, saat ia tertangkap tentara Rasul.

Ibn Ustal adalah tokoh besar yang selama ini menentang dakwah Muhammad saw. Dia terus melakukan perlawanan, bahkan pengejekan (perendahan) atas pribadi Muhammad saw saat menjadi tahanan. Mengingat ketokohannya, Nabi memperlakukan Ibn Ustal secara istimewa dengan melayani sendiri Ibn Ustal, setiap pagi memberi sarapan susu onta. Namun Ibn Ustal justru sebaliknya, selalu merendahkan Rasul dengan menawari jabatan atau harta dengan syarat Nabi menghentikan dakwahnya. Perlakuan demikian berlangsung kurang lebih satu minggu yang selalu dibalas Ibn Ustal dengan sikap merendahkan.

Seminggu berselang, Nabi memerintahkan para sahabat untuk melepaskan Ibn Ustal tanpa syarat. Bingung campur tidak percaya menghadapi perlakuan yang di luar logika manusia atas pembebasan dirinya tanpa syarat tersebut, Ibn Ustal lalu pergi meninggalkan kawasan Madinah. Tiba di suatu tempat, Ibn Ustal lalu bersuci (berwudu) lalu bergegas kembali ke kawasan Masjid Nabawi menemui Nabi yang masih dikelilingi para sahabat. 
Dengan lantang ia bersumpah bahwa selama ini tidak ada orang yang paling ia benci di dunia ini kecuali Muhammad. Ia melanjutkan bersumpah bahwa sejak detik ia dibebaskan tanpa syarat itu, maka tidak ada di dunia ini orang yang paling ia cintai, kecuali Muhammad Rasulullah saw.

Perubahan konversi radikal Ibn Ustal dari kafir menjadi beriman di atas tidak lain karena tersentuh aksi kemanusiaan (humanis) Rasul Muhammad saw. Ibn Ustal berfikir bahwa Muhammad bukanlah manusia biasa seperti manusia pada umumnya ketika membebaskan orang yang selama ini memusuhi yang ketika menjadi tahanan masih tetap melakukan perlawanan. Kisah kemanusiaan ini bisa dibaca dari buku-buku sirah nabawi yang mengurai kegiatan dakwah Rasulullah secara lebih detail dan rinci.

Kisah di atas memberi pelajaran berharga bahwa proses perubahan seseorang menjadi beriman atau memperoleh hidayah bisa amat beragam. Menjadi muslim atau santri, abangan atau mutihan, melalui jalan dan penyebab yang beragam. Demikian pula beragam kelompok masyarakat tertarik dan terlibat aktif dalam berbagai gerakan Islam di Tanah Air. Hal ini menandai keragaman praktek keberagamaan setiap orang.

Salah satu tokoh gerakan Islam terkemuka di Tanah Air, seperti Kiai Ahmad Dahlan, melakukan dakwah dan pendidikan melalui cara-cara yang juga beragam. Kiai Ahmad Dahlan meluruskan kiblat, dialog dan diskusi, mendirikan panti asuhan, rumah sakit, kepanduan, sekolah, mendidik dan menyebarkan guru desa, mendorong peran sosial kaum perempuan. Melalui cara beragam inilah dalam tempo singkat membuat Muhammadiyah berkembang pesat selama kepemimpinan Kiai Ahmad Dahlan ketika itu.

Dalam kaitan itu praktik keagamaan kaum abangan dan yang sejenis perlu dipahami sebagai proses menjadi muslim yang belum selesai, seperti juga menjadi santri yang tak akan pernah berakhir (Pratiknya 1998). Karena itu menjadi aktivis gerakan Islam, menjadi orang saleh, dan atau menjadi santri 
Jalan Tuhan dan Kemanusiaan dalam Pendidikan adalah sebuah proses penemuan diri yang terus menerus berubah sepanjang hidup seseorang atau masyarakat. Demikian pula menjadi berkepribadian ideal, yang karena itu pendidikan sudah semestinya memberi bekal peserta didik untuk terus tumbuh menjadi pribadi ideal, seorang yang saleh sekaligus professional. 


\section{BIBLIOGRAPHY}

Amstrong, Karen, 2001. Berperang Demi Tuhan: Fundamentalisme dalam Islam, Kristen dan Yahudi. Jakarta-Bandung: Serambi Ilmu Semesta \& Mizan.

Anderson, Lorin W. and Krathwohl, David R. (eds.). 2001. A Taxonomy for Learning, Teaching, and Assessing; A Revision of Bloom's Taxonomy of Educational Objevtives. New York: Longman.

Freire, Paulo. 1985. Pendidikan Kaum Tertindas. Jakarta: LP3ES.

Freire, Paulo. 1999. Politik Pendidikan Kebudayaan, Kekuasaan dan Pembebasan. Yogyakarta: Read dan Pustaka Pelajar

Marsden, George M. 1996. Agama dan Budaya Amerika, Jakarta: Sinar Harapan.

Miller, John P. 1976. Humanizing the Classroom: Model of Teaching in Affective Education. New York: Praeger Publisher.

Miller, John P. 2002. Sekolah Kepribadian, saduran Abdul Munir Mulkhan. Yogyakarta: Kreasi Wacana.

Mulkhan, Abdul Munir, 2002. "Pembelajaran Islam Model Garden Learning", Lokakarya "Reorientasi Pembelajaran Mata Kuliah Pengembangan Kepribadian (MPK) Agama" Yogyakarta: UII.

Mulkhan, Abdul Munir, 2002. Nalar Spiritual: Solusi Problem Filosofis Pendidikan Islam. Yogyakarta: Tiara Wacana.

Mulkhan, Abdul Munir. 2002. "Dakwah Kultural dalam Tradisi Keberagamaan di Indonesia", Sidang Tanwir Muhammdiyah 24-27 Januari 2002 di Bali.

Nasution. 1982. Teknologi Pendidikan. Bandung: Jemmars.

Pratiknya, Ahmad W. 1998. Islam dan Dakwah: Pergumulan Nilai dan Realitas. Yogyakarta: PP Muhammadiyah Majlis Tabligh. 